\title{
The Effect of Epidural Application of FSH on Superovulatory Response in Eastern Anatolian Red Cow
}

\author{
Muharrem Satılmışs ${ }^{1, *}\left(\mathbb{D}\right.$, Mehmet Ali Yılmaz $^{2}{ }^{(0)}$, Ramazan Sevgi ${ }^{2}{ }^{D}$, Tahir \\ Karaşahin $^{3}\left(\mathbb{D}\right.$, Sedat Hamdi Kızıl ${ }^{4}\left(\mathbb{D}\right.$, Alaeddin Okuroğlu² ${ }^{2}$, Talha Burak Ertem ${ }^{2}(\mathbb{D}$, \\ Zulal Tavlı Yıldırır ${ }^{5}$ \\ 1'zmir Bakırçay University, Menemen Vocational School, Department of Veterinary, İzmir Turkey \\ ${ }^{2}$ International Center For Livestock Research and Training, Ankara, Turkey \\ ${ }^{3}$ Aksaray University, Faculty of Veterinary Medicine, Department of Physiology, Aksaray, Turkey \\ ${ }^{4}$ Kırıkkale University, Faculty of Veterinary Medicine, Department of Reproduction and Artificial Insemination, \\ Kırıkkale, Turkey \\ ${ }^{5}$ Aegean Agricultural Research Institute, İzmir, Turkey \\ *Corresponding author
}

\section{Article History}

Received: 18 May 2021

Accepted: 12 Dec 2021

First Online: 22 Dec 2021

\section{Corresponding Author}

E-mail:

muharrem.satilmis@bakircay.edu.tr

\section{Keywords \\ Embryo \\ Eastern Anatolian Red \\ Epidural \\ FSH}

Superovulation

\begin{abstract}
This study aimed to evaluate the superovulation response in Eastern Anatolian Red (EAR) cows treated with a single epidural injection or traditional administration of follicle stimulating hormone (FSH). Eight cows were randomly divided into two groups, as control (CG) and experiment (EG). Four replications were applied for each animal in the groups. A total of 16 studies were carried out in each group. In this study, $300 \mathrm{mg}$ intramuscular (i.m) FSH injection was applied with decreasing doses twice daily for four days to the cows in the CG. (70:70, 50:50, 20:20, 10:10 mg). On the other hand, $300 \mathrm{mg}$ FSH was administered as $150 \mathrm{mg}$ epidural and $150 \mathrm{mg}$ intramuscular injection to the cows in EG. The number of untransferable embryos and the total CLs were found statistically significant $(p<0.05)$. However, the number of transferable embryos and unfertilized oocyte (UFO) were found statistically insignificant among the groups $(p>0.05)$. According to the obtained data, it was observed that the epidural administration of FSH for superovulation in EAR cows did not provide sufficient follicle and oocyte development. In conclusion, different studies with different superovulation protocols and FSH doses in local breed EAR cows will be needed for further studies.
\end{abstract}

\section{Introduction}

In recent years, in the world, there has been a significant increase in studies for animal genetic resource conservation. Strategic priority issues have been determined in line with the Global Plan of Action for Animal Genetic Resources and, many countries have accepted that they have the priority protection task. In almost all economically developed countries, the genetic resources have been taken under preservation by carrying out national projects for animal genetic resource conservation. (Hiemstra et al., 2004). Many countries have established gene banks to protect animal genetic resources, and in this bank, they have started to conserve the genetic materials such as semen, embryos, and DNA of the endangered native breeds (Bailey et al., 2000; Medeiros et al., 2002).
Some technologies have been used for animal genetic resource conservation and obtaining genetic materials. Embryo transfer technology is one of the technologies used to obtain the genetic material to be frozen. Embryos obtained from animals whose genetic materials are frozen (in vivo) or from gamete cells of the animals in the laboratory (in vitro) are frozen and stored. (Machaty et al., 2012; Kaymaz et al., 2015).

Embryo transfer technology consists of various processes. Superovulation protocol, which includes the utilization of hormones, is one of the most significant steps of the process series (Hasler, 2006; Machaty et al., 2012). Different hormones and administration protocols are used to achieve superovulation (Mapletoft et al., 2002). FSH is one of the most common hormones used in ovarian 
stimulation in cattle (Sağırkaya, 2009). However, FSH is a hormone with a very short half-life (about 5 hours or less). For this reason, FSH is treated twice daily at 12 hours intervals (Monniaux et al., 1983; Machaty et al., 2012; Bó \& Mapletoft, 2014).

Since FSH has a short duration of action, multiple applications increase stress in animals and labor. Different protocols are studied to extend the duration of FSH action and reduce the number of injections. In a study, when FSH was mixed with a $30 \%$ polyvinylpolypyrrolidone (PVP) solution and administered as a single intramuscular injection, similar results to the classical method were found. (Yamamoto et al., 1994). Another study reported that when a mixture of FSH, PVP, and equine chorionic gonadotropin (eCG) was administered as a single injection, a super stimulatory response similar to the traditional FSH protocol could be achieved (Bó \& Mapletoft, 2014).

In recent years, there have been studies in which gels containing aluminum hydroxide are used as vaccine adjuvants to ensure the slow release of FSH (Baylor et al., 2002; Lindblad, 2004). Kimura et al. (2007) reported that an aluminum hydroxide gel and FSH mixture application, as a single injection, provides sufficient effect in cattle. However, it was reported that aluminum hydroxide gel intramuscular injections cause lesions in the injection areas, thus causing economic losses in meat production (Kimura, 2016).

Another study showed that FSH suspension diluted in $2 \%$ hyaluronan provided sufficient super stimulatory response. However, obtaining a homogeneous mixture with FSH was reported as problematic due to the high viscosity of hyaluronan. Therefore, it was illustrated that the suspension obtained with lower concentrations of hyaluronan has better results when administered as two injections at 48 hours intervals (Tríbulo et al., 2011; Tríbulo et al., 2012). In a study on
Anatolian Black cow, Taşdemir et al. showed that a single epidural injection with intramuscular injection of FSH application could provide acceptable results compared to twice-daily injection of FSH for super stimulatory response (Taşdemir et al., 2012).

Eastern Anatolian Red cows are one of our local breeds. Moreover, EAR cows and their genetic materials (sperm, embryo, DNA, and cells) are preserved in the gene bank within the scope of genetic resources. However, there are not enough embryos of these cows in the gene bank. This study aims to determine the efficiency of single epidural injection compared with traditional administration of FSH on superovulation response in EAR donor cows.

\section{Materials and Methods}

Eight cows 3-4 years old were used in this study. The cows had the same treatments and feeding conditions in the International Center for Livestock Research and Training. $400 \mathrm{mg}$ FSH (FOLLTROPIN ${ }^{\circledR}$ Bioniche, Ireland), 1.55 g. Progesterone (Eazi Breed, $\mathrm{CIDR}^{\circledR}$, Pfizer, Australia) and PGF2 $\alpha$ (ESTRUMATE ${ }^{\circledR}$, Intervet, Turkey) were used for superovulation protocol. Lactated Ringer's Solution (Polifarma, Turkey), Dual-way balloon catheter (Bioniche) were used for uterine flushing of donors. A 75 microns emcon filter (Agtech) was used to collect the flashing solution.

Animals were randomly divided into two groups, as control (CG) and experiment (EG). Four replications were applied for each animal in the groups. After each study, animals were kept for two months without any treatment. In addition, each animal was taken into a different group in the next repetition and, the study was carried out. Thus, the consequences arising from individual differences

Table 1. Application of FSH to the control group (CG) (Imai, 2005; Taşdemir et al., 2012).

\begin{tabular}{|c|c|c|c|c|c|c|c|c|c|c|c|c|}
\hline \multirow{2}{*}{$\begin{array}{c}\text { First (0) } \\
\text { Day } \\
08: 00 \\
\text { Am } \\
\end{array}$} & \multicolumn{2}{|c|}{$\begin{array}{l}\text { 7th } \\
\text { Day }\end{array}$} & \multicolumn{2}{|c|}{$\begin{array}{l}\text { 8th } \\
\text { Day }\end{array}$} & \multicolumn{4}{|c|}{$\begin{array}{l}\text { 9th } \\
\text { Day }\end{array}$} & \multicolumn{2}{|c|}{$\begin{array}{l}\text { 10th } \\
\text { Day }\end{array}$} & $\begin{array}{l}\text { 11th } \\
\text { Day }\end{array}$ & \multirow{2}{*}{$\begin{array}{c}\begin{array}{c}\text { 18th } \\
\text { Day }\end{array} \\
\text { 08:00 Am } \\
\text { 10:00 Pm }\end{array}$} \\
\hline & $\begin{array}{c}\text { 08:00 } \\
\text { Am }\end{array}$ & $\begin{array}{c}\text { 08:00 } \\
\text { Pm }\end{array}$ & $\begin{array}{l}\text { 08:00 } \\
\text { Am }\end{array}$ & $\begin{array}{l}\text { 08:00 } \\
\text { Pm }\end{array}$ & 08:00 & Am & 08:00 & $0 \mathrm{Pm}$ & $\begin{array}{l}\text { 08:00 } \\
\mathrm{Am}\end{array}$ & $\begin{array}{c}\text { 08:00 } \\
\text { Pm }\end{array}$ & \begin{tabular}{|c|c|} 
08:00 & $08: 00$ \\
Am & Pm
\end{tabular} & \\
\hline $\begin{array}{c}\text { CIDR } \\
\text { Placement }\end{array}$ & $\begin{array}{c}\text { FSH } \\
(70 \mathrm{mg})\end{array}$ & $\begin{array}{c}\text { FSH } \\
(70 \mathrm{mg})\end{array}$ & $\begin{array}{l}\text { FSH } \\
(50 \mathrm{mg})\end{array}$ & $\begin{array}{c}\text { FSH } \\
(50 \mathrm{mg})\end{array}$ & $\begin{array}{l}\text { FSH } \\
(20 \mathrm{mg})\end{array}$ & $\begin{array}{l}\text { PGf2a } \\
(3 \mathrm{ml})\end{array}$ & $\begin{array}{c}\text { FSH } \\
(20 \mathrm{mg})\end{array}$ & $\begin{array}{c}\text { CIDR } \\
\text { Remove }\end{array}$ & $\begin{array}{l}\text { FSH } \\
(10 \mathrm{mg})\end{array}$ & $\begin{array}{c}\text { FSH } \\
(10 \mathrm{mg})\end{array}$ & Al & $\begin{array}{l}\text { USG/Flushing } \\
\text { (Emb.Recover) }\end{array}$ \\
\hline
\end{tabular}

Table 2. Application of FSH to the experimental group (EG) (Imai, 2005; Taşdemir et al., 2012).

\begin{tabular}{|c|c|c|c|c|c|c|c|}
\hline $\begin{array}{l}\text { First (0) } \\
\text { Day }\end{array}$ & \multicolumn{2}{|c|}{$\begin{array}{l}\text { 7th } \\
\text { Day }\end{array}$} & \multicolumn{2}{|c|}{$\begin{array}{l}\text { 9th } \\
\text { Day }\end{array}$} & \multicolumn{2}{|c|}{$\begin{array}{l}\text { 11th } \\
\text { Day }\end{array}$} & $\begin{array}{l}\text { 18th } \\
\text { Day }\end{array}$ \\
\hline $\begin{array}{l}\text { 08:00 } \\
\text { Am }\end{array}$ & $\begin{array}{l}\text { 08:00 } \\
\text { Am }\end{array}$ & $\begin{array}{l}\text { 08:00 } \\
\text { Am }\end{array}$ & $\begin{array}{l}\text { 08:00 } \\
\text { Am }\end{array}$ & $\begin{array}{l}\text { 08:00 } \\
\text { Pm }\end{array}$ & $\begin{array}{l}\text { 08:00 } \\
\text { Am }\end{array}$ & $\begin{array}{l}\text { 08:00 } \\
\text { Pm }\end{array}$ & $\begin{array}{l}\text { 08:00 Am } \\
\text { 10:00 Pm }\end{array}$ \\
\hline $\begin{array}{c}\text { CIDR } \\
\text { Placement }\end{array}$ & $\begin{array}{c}\text { FSH } \\
\text { (Epidural } 150 \mathrm{mg} \text { ) }\end{array}$ & $\begin{array}{c}\text { FSH } \\
\text { (Im } 150 \mathrm{mg})\end{array}$ & $\begin{array}{l}\text { PGf2a } \\
(3 \mathrm{ml})\end{array}$ & $\begin{array}{c}\text { CIDR } \\
\text { Remove }\end{array}$ & & Al & $\begin{array}{l}\text { USG/Flushing } \\
\text { (Emb.Recover) }\end{array}$ \\
\hline
\end{tabular}


between the groups were minimized. CIDR containing $1.56 \mathrm{~g}$ progesterone was inserted into the cows on a random day of the cycle. This application day was accepted as day 0 . Cows were divided into two groups on the 7th day of CIDR application according to FSH dose and route of FSH administration (Folltropin). In the CG group, $300 \mathrm{mg}$ intramuscular (i.m) FSH injection was applied with decreasing doses twice-daily for four days. (70:70, 50:50, 20:20, 10:10 mg; n: 4 Table 1). However, $150 \mathrm{mg}$ epidural FSH and $150 \mathrm{mg}$ i.m FSH injection applied to the EG on day 7 of the cycle ( $n$ : 4; Table 1). 9 days later the beginning of the superovulation program, PGF2 $\alpha$ injection was administered to both groups in the morning, and the CIDR was removed in the evening. After the observation of oestrus symptoms on day 11 and day 12, artificial insemination was performed twice at 12 hours intervals by using frozen semen of the EAR bulls.

\section{Results}

In the study, as a result of superovulation with decreasing doses of FSH in CG animals; the number of UFOs, the number of untransferable embryos, the number of the transferable embryos, the number of $\mathrm{CL}$, the number of total ovum/embryo, and the embryo recovery rate were $1.75 \pm 0.479,2.11 \pm 0.588,1.50 \pm 0.289$, $5.54 \pm 0.666,2.92 \pm 0.571$ and $41,4 \%$, respectivel. As a result of superovulation with single epidural and intramuscular FSH application in EG animals, the number of UFOs was $1.67 \pm 0.667$, the number of untransferable embryos was $1.00 \pm 0.000$, the number of transferable embryos was 1 , the number of $C L$ was $3.25 \pm 0.675$, the total number of ovum/embryo was $1.13 \pm 0.441$, and the embryo recovery rate was $43,3 \%$ (Table 3 ).

The ratio of the total number of the obtained ovum/embryos to the CLs was $41.1 \%(7 / 41)$ in CG and $43.7 \%(7 / 16)$ in EG. In addition, the average number of total ovum/embryo obtained per donor was 1.06 (17/16) in CG and $0.43(7 / 16)$ in EG. The ratio of the number of transferable embryos to the total number of ovum/embryo was 0.23 (4/17) in CG and 0.14 (1/7) in EG.
According to the results, there was no statistically significant difference between the CG and EG groups in the number of UFOs, the number of untransferable embryos, and the embryo recovery rates $(P>0.05)$. However, It was determined that the total number of $\mathrm{CL}$ and ovum/embryo obtained from the control group was higher than the experimental group $(P<0.05)$.

\section{Discussion and Conclusion}

Currently, the successful results in the superovulation protocols applied with FSH can not be achieved in local breeds as obtained in the exotic breeds. Responses of the applied oestrus synchronization and superovulation programs can still vary. While superovulation responses of some local breeds to are adequate, some may lack such potential. Studies on superovulation protocols specific to local breeds and FSH doses are needed (Kelly et al., 1997; Bó et al., 2002; Bó et al., 2003; Baruselli et al., 2006). Some researchers have reported that it may be possible to achieve higher results in local breeds with the appropriate superovulation protocol selection (Bó et al., 1996; Bó et al., 2002; Carvalho, 2004)

In this study, the CL numbers counted by USG were found to be higher in CG animals than in EG animals. However, the results in both groups are low compared with the exotic breeds. In a similar study on local breed White Yak cattle, Yu reported that they received a low number of $C L$ in a superovulation program that included twice-daily $\mathrm{FSH}$ administration in decreasing doses for four days. Thus, the results of our study are similar to Yu et al.'s study (Yu et al., 2007).

The number of UFOs, untransferable and transferable embryos, and the embryo recovery rate were not statistically different between the CG and EG groups. However, the total $\mathrm{CL}$ and total ovum/embryos obtained from the CG were higher

Table 3. Number of UFO, untransferable embryo, transferable embryo, $\mathrm{CL}$, total ovum / embryo and embryo recovery rate in groups.

\begin{tabular}{|c|c|c|c|c|c|c|c|}
\hline Groups & $\stackrel{n}{\mathrm{X}} \pm \mathrm{S}_{\overline{\mathrm{X}}}$ & $\begin{array}{l}\text { Number of } \\
\text { unfertilized } \\
\text { oocyte }\end{array}$ & $\begin{array}{c}\text { Number of } \\
\text { untransferable } \\
\text { embryo }\end{array}$ & $\begin{array}{c}\text { Number of } \\
\text { transferable } \\
\text { embryo }\end{array}$ & Number of $\mathrm{CL}$ & $\begin{array}{l}\text { Number of total } \\
\text { ovum/embryo }\end{array}$ & $\begin{array}{c}\text { Recovery } \\
\text { rate \% }\end{array}$ \\
\hline CG & 16 & $\begin{array}{c}4 \\
(1,75 \pm 0,479)\end{array}$ & $\begin{array}{c}9 \\
(2,11 \pm 0,588)\end{array}$ & $\begin{array}{c}4 \\
(1,50 \pm 0,289)\end{array}$ & $\begin{array}{c}41 \\
(5,54 \pm 0,666(a)\end{array}$ & $\begin{array}{c}17 \\
(2,92 \pm 0,571)(a)\end{array}$ & $\begin{array}{l}41,4 \% \\
(17 / 41)\end{array}$ \\
\hline EG & 16 & $\begin{array}{c}3 \\
(1,67 \pm 0,667)\end{array}$ & $\begin{array}{c}3 \\
(1,00 \pm 0,000)\end{array}$ & $\begin{array}{c}1 \\
(1)\end{array}$ & $\begin{array}{c}16 \\
(3,25 \pm 0,675)(b)\end{array}$ & $\begin{array}{c}7 \\
(1,13 \pm 0,441)(b)\end{array}$ & $\begin{array}{l}43,3 \% \\
(7 / 16)\end{array}$ \\
\hline $\begin{array}{c}{ }^{* p} \\
\text { value }\end{array}$ & & 0,844 & 0,267 & & 0,036 & 0,036 & \\
\hline
\end{tabular}

$\mathrm{a}, \mathrm{b}$ : The difference between different letters in the same column is significant $(\mathrm{P}<0.05)$. 
than the EG. The results in both groups are lower compared with other studies (Taşdemir el al., 2012; Satılmış et al., 2017). It is considered that genetics, environment, nutrition, breed, season, age, the condition of the ovary at the time of application, and the effects of repeated superovulation can be the reasons for the differences in the ovary responses. Also, it is considered that the dose of the administered hormone, the timing of administration, and the use of additional hormones in superovulation protocols can be the other factors causing the differences (Sugano, \& Watanabe, 1997; Son et al., 2007). There are various studies on determining the appropriate dose and FSH administration methods to eliminate the stress due to multiple FSH injections in cattle (Alvarez et al., 2010; Bó et al., 2010). It was reported in these studies that similar results were obtained by intramuscular or subcutaneous (SC) applications of a single FSH treatment (Kanitza et al., 2002; Alvarez et al., 2010).

The number of total ovum/embryos obtained per animal was $1.06(17 / 16)$ in CG and $0.43(7 / 16)$ in EG. It can be claimed that these rates are low compared to the averages of both cultural and local breeds (Karasahin et al., 2016). It is considered that these low embryo rates may be due to the low reproductive performance in EAR cows. It was stated in a study on the Anatolian Black cows that the results were similar for the superovulation induced by intramuscular administration with FSH applied to the epidural space compared with $\mathrm{FSH}$ treated in decreasing doses. However, transferable embryo rates were found low in both groups. The results of our study and the study on the Anatolian Black cows are similar (Taşdemir et al., 2012).

In the study, the ratio of the UFO $(23.5 \%$ in CG; $42.8 \%$ in EG ) was similar between the groups. It has been stated that the UFO rate varied between $23.5 \%$ and $39 \%$ in previous studies conducted with different breeds (Karasahin et al., 2016). The UFO rates we obtained in our study are similar to previous studies (Taşdemir et al., 2016).

In the study, the ratio of the total number of embryos / ovums and the total number of CL was 41.4 $\%(17 / 41)$ in CG and $43.7 \%(7 / 16)$ in EG. Although it was higher in the control group, it was lower than the studies on other local breeds and culture breeds. It is considered that these low rates are due to the breed and superovulation protocols (Kelly et al., 1997; Kim et al., 2000; Sugano et al., 2001; Barati et al., 2006). After more than 30 years of studies in Bos indicus, it is emphasized that the superovulation response in these animals, in which ovarian and follicular dynamics have been largely clarified, is better than Bos Taurus. However, this response also depends on environmental conditions such as care and feeding (Sağırkaya, 2009).

In this study, the rates of transferable embryo in both groups were ( $23.5 \%$ in CG; $14.2 \%$ in EG ). This ratio was lower than other local breeds (Sistani: 49\%, Angus: 52\%, Finnish Ayrshire: 61\%, Korean Native: 62\%, and Japanese Black: 53\%) (Sugano et al., 2001; Barati et al.,
2006). However, the results of the studies conducted in Nelore cattle yielded were similar to the results we obtained in our study (Alvarez et al., 2010). It was reported that the difference and lowness of these results in local breeds could be due to the decrease in the number of growing follicles (Lopes et al., 2007).

As a result, it was concluded that the Eastern Anatolian Red cattle breed does not have the potential to provide a superovulation response with a high success rate compared with culture breeds. However, advanced studies are needed to reveal the reproduction parameters of this breed to increase the number of transferable embryos. Moreover, the superovulation protocol approaches need to be improved in light of these studies.

\section{Acknowledgements}

This study was supported by General Directorate of Agricultural Research and Policies. (Department of Animal Husbandry and Aquaculture Research)

\section{References}

Alvarez, R.H., Martinez, A.C., Pires, R.M.L. (2010). Superovulatory response of Zebu cows treated with pFSH in a single subcutaneous injection followed by an additional intramuscular sub-dose $48 \mathrm{~h}$ later. Reproduction in Domestic Animals, 45 (3):421-4. doi: 10.1111/j.1439-0531.2008.01209.x

Bailey, J.L., Blodeau, J.F., \& Cormier, N. (2000). Semen cryopreservation in domestic animals: A damaging and capacitating phenomenon minireview. Copyrightq American Society of Andrology, 21(1):17. doi.org/10.1002/j.1939-4640.2000.tb03268.x.

Barati F, Niasari-Naslaji A, Bolourchi M, Sarhaddi F, Razavi K, Naghzali E, \& Thatcher, W.W. (2006). Superovulatory response of Sistani cattle to three different doses of FSH during winter and summer. Theriogenology, 66 (5):1149-55. doi: 10.1016/j.theriogenology.2006.03.026.

Baruselli, P.S., de Sá Filho, M.F., Martins, C.M., Nasser, L.F., Nogueira, M.F.G., Barros, C.M., \& Bó, G.A. (2006): Superovulation and embryo transfer in Bos indicus cattle. Theriogenology, 65 (1): 77-88. doi: 10.1016/j.theriogenology.2005.10.006.

Baylor, N.W., Egan, W., \& Richman, P. (2002). Aluminum salts in vaccines-US perspective. Vaccine, 20:S18-23. doi: 10.1016/s0264-410x(02)00166-4.

Bó, G.A., Baruselli, P.S., Moreno, D., Cutaia, L., Caccia, M., Tribulo, R., Tríbulo, H., Mapletoft, R.J. (2002). The control of follicular wave development for selfappointed embryo transfer programs in cattle. Theriogenology, 57 (1): 53-72. doi: 10.1016/s0093691x(01)00657-4.

Bó, G.A., Baruselli, P.S., Martınez, M.F. (2003): Pattern and manipulation of follicular development in Bos indicus cattle. Animal Reproduction Science, 78 (3): 307-326. doi: 10.1016/s0378-4320(03)00097-6.

Bó, G.A., \& Mapletoft, R.J. (2014). Historical perspectives and recent research on superovulation in cattle. Theriogenology, 81(1):38-48. doi: 10.1016/j.theriogenology.2013.09.020. 
Bó, G.A., Guerrero, D.C., Tríbulo, A., Tríbulo, H., Tríbulo, R., Rogan, D., Mapletoft, R.J. (2010). New approaches to superovulation in the cow. Reproduction, Fertility and Development, 22(1):106-12. doi: 10.1071/RD09226.

Bó, G.A., Adams, G.P., Pierson, R.A., \& Mapletoft, R.J. (1996): Effect of progestogen plus E-17b treatment on superovulatory response in beef cattle. Theriogenology, 45(5): 897-910. doi: 10.1016/0093-691x(96)00020-9.

Carvalho, J.B.P. (2004). Synchronization of ovulation with intravaginal with progesterone device in Bos indicus, Bos indicus $x$ Bos taurusand Bos taurus heifers. Ph.D. Thesis, University of SãoPaulo, Brasil, 2004.

Hasler, J.F. (2006). The Holstein cow in embryo transfer today as compared to 20 years ago. Theriogenology, 65 (1):4-16. doi: 10.1016/j.theriogenology.2005.10.002.

Hiemstra, S.J. (2004).Guidelines for the constitution of national cryopreservation programmes for farm animals. European Region Focal Point For Animal Genetic Resources. Available in: http://www.agrowebcee.net/ fileadmin/content/aw lithuania/files/Guidelinest.pdf.

Imai, K. (2005). Embryo Transfer Technology For Domestic Animal. Fucushima, Japan: Japan International Cooperation Agency National Livestock Breeding Center.

Kanitza, W., Beckera, F., Schneidera, F., Kanitzb, E., Leidingc, C., Nohnerc, H.P., \& Pöhlanda, R. (2002). Superovulation in cattle: practical aspects of gonadotropin treatment and insemination. Reproduction Nutrition Development, 42 (6):587-99. doi: 10.1051/rnd:2002045.

Karaşahin, T., Kızıl, S.H., Satılmış, M., Akyol, N., Dursun, Ş., \& Kırbaş, M (2016). Investigation of the response of different breeds to the superovulation treatment. JAVST; 1(1): 1-5.

Kaymaz, M., Fındık, M., Rişvanlı, A., \& Köker, A. (2015). Obstetrics and Gynecology in Farm Animals. Medipres Matbaacılık Ltd. Şti., pp. 660-84. ISBN:978-605-9720-24-3.

Kelly, P., Duffy, P., Roche, J.F., \& Boland, M.P. (1997). Superovulation in cattle: effect of FSH type and method of administration on follicular growth, ovulatory response and endocrine patterns. Animal Reproduction Science, 46 (1-2):1-14. doi: 10.1016/s0378-4320(96)01589-8.

Kim, I.H., Son, D.S., Yeon, S.H., Choi, S.H., Park, S.B., Ryu, I.S., Suh, G.H., Lee, D.W., Lee, C. S., Lee, H. J., \& Yoon, J.T. (2000). Effect of dominant follicle removal before superstimulation of follicular growth, ovulation and embryo production in Holstein cows. Theriogenology, 55 (4):937-45. doi: 10.1016/s0093-691x(01)00455-1.

Kimura, K., Hirako, M., Iwata, H., Aoki, M., \& Kawaguchi, M. Seki M. (2007). Successful superovulation of cattle by a single administration of FSH in aluminum hydroxide gel. Theriogenology, 68(4):633-9.doi: 10.1016/j.theriogenology.2007.02.016.

Kimura, K. (2016). Superovulation with a single administration of FSH in aluminum hydroxide gel: a novel superovulation method for cattle. Journal of Reproduction and Development, 62(5):423-9. doi: 10.1262/jrd.2016-066.

Lindblad, E.B. (2004). Aluminium adjuvants-in retrospect and prospect. Vaccine, 22 (27-28):3658-68. doi: 10.1016/j.vaccine.2004.03.032.

Lopes, A.S., Butler, S.T., Gilbert, R.O., \& Butler, W. (2007). Relationship of pre-ovulatory follicle size, estradiol concentrations and season to pregnancy outcome in dairy cows. Animal reproduction science, 99 (1-2):34-43. doi: 10.1016/j.anireprosci.2006.04.056.

Machaty, Z., Peippo, J., \& Peter, A. (2012). Production and manipulation of bovine embryos: techniques and terminology. Theriogenology, 78 (5):937-50. doi: 10.1016/j.theriogenology.

Mapletoft, R.J., Steward, K.B., \& Adams, G.P. (2002). Recent advances in the superovulation in cattle. Reproduction Nutrition Development, 42 (6):601-11. doi: 10.1051/rnd:2002046.

Medeiros C.M.O., Forell, F., Oliveira, A.T.D., \& Rodrigues, J.L. (2002). Current status of sperm cryopreservation: why isn't it better? Theriogenology, 57(1):327- 44. doi: 10.1016/s0093691x(01)00674-4.

Monniaux, D., Chupin, D., \& Saumande, J. (1983). Superovulatory responses of cattle. Theriogenology, 19 (1):55-81. doi.org/10.1016/0093-691X(83)901243.

Taşdemir, U., Satılmış, M., Karaşahin, T., Kızıl, S.H., Kaymaz, M., \& Imai, K. (2012). The effect of single epidural plus intramusculer injection of FSH on superovulatory response in Anatolian Black cow. Veterinary Journal of Ankara University, 59:211-216. doi: 10.1501/Vetfak.

Taşdemir, U., Karaşahin, T., Satılmış, M., Kızıl, S.H., \& Kaymaz, M (2016). Various FSH administration on superovulatory response and embryo yield in Anatolian Black heifers. Kocatepe Vet J; 9 (4): 322326

Tríbulo, A., Rogan, D., Tribulo, H., Tribulo, R., Alasino, R.V., Beltramo, D., Bianco, I., Mapletoft, R.J., \& Bó, G.A. (2011). Superstimulation of ovarian follicular development in beef cattle with a single intramuscular injection of Folltropin-V. Animal Reproduction Science, 129 (1-2):7-13. doi: 10.1016/j.anireprosci.2011.10.013.

Tríbulo, A., Rogan, D., Tríbulo, H., Tríbulo, R., Mapletoft, R.J., \& Bó, G.A. (2012). Superovulation of beef cattle with a split-single intramuscular administration of Folltropin- $\mathrm{V}$ in two concentrations of hyaluronan. Theriogenology, doi:10.1016/j.theriogenology.2011.12.013.

Sağırkaya, H. (2009). Embryo transfer in cattle and the importance of embryo transfer for Turkey. Uludag University Journal of Research in Veterinary Medicine, 28 (2): 11-19.

Satılmış, M., Akyol, N., Kızıl, S.H., \& Karaşahin, T (2012). The investigation of superovulation responses with different protocols in Anatolian Native Black heifers. Lalahan Hay. Araşt. Enst. Derg. 57: (1) 13-17. http://arastirma.tarim.gov.tr/lalahan.

Sugano, M., \& Watanabe S. (1997). Use of highly purified porcine FSH preparation for superovulation in Japanese black cattle. Journal of Veterinary Medical Science, 59 (3):223-5. doi: 10.1292/jvms.59.223.

Sugano, M., Shinogi, T., Nakada, K., \& Nakao, T. (2001). Endocrine profiles and embryo quality in Japanese black cattle superovulated with human menopausal gonadotrophin and porcine follicle stimulating hormone. Reproduction in Domestic Animals, 36 (2):57-63. doi: 10.1046/j.1439-0531.2001.00192.x.

Son, D.S., Choe, C.Y., Choi, S.H., Cho, S.R., Kim, H.J., Han, M.H., Ryu, I.S., Suh, G.H., Kim, U. H., Kim, I.H. (2007). Effect of estradiol benzoate or GnRH treatment prior to superstimulation in CIDR-treated, Korean native cows (Bos taurus). Animal Reproduction Science, 100(1-2):14-21. doi: 10.1016/j.anireprosci.2006.06.005. 
Yamamoto, M., Ooe, M., Kawaguchi, M., \& Suzuki, T. (1994). Superovulation in the cow with a single intramuscular injection of $\mathrm{FSH}$ dissolved in polyvinylpyrrolidone. Theriogenology, 41(3):747-55. doi: 10.1016/0093-691x(94)90184-k.
Yu, S., Ju, X.H., Wang, L.B., Fan, \& J.F. (2007). Successful embryo transfer in Tianzhu white yak using standard protocol. Science in China Series C Life Sciences 50 (5):655-9. doi: 10.1007/s11427-007-0062-9. 